\title{
Plasminogen deficiency causes severe thrombosis but is compatible with development and reproduction
}

\author{
Thomas H. Bugge, ${ }^{1,3}$ Matthew J. Flick,' Cynthia C. Daugherty, ${ }^{2}$ and Jay L. Degen ${ }^{1,4}$ \\ Divisions of Basic Science Research ${ }^{1}$ and Pathology ${ }^{2}$ Children's Hospital Research Foundation, Cincinnati, Ohio 45229 \\ USA; Finsen Laboratory, ${ }^{3}$ Rigshospitalet, DK-2100 Copenhagen, Denmark
}

\begin{abstract}
Plasminogen (Plg)-deficient mice were generated to define the physiological roles of this key fibrinolytic protein and its proteolytic derivatives, plasmin and angiostatin, in development, hemostasis, and reproduction. $\mathrm{Plg}^{-\prime-}$ mice complete embryonic development, survive to adulthood, and are fertile. There is no evidence of fetal loss of $\mathrm{Plg}^{-1-}$ mice based on the Mendelian pattern of transmission of the mutant $\mathrm{Plg}$ allele.

Furthermore, embryonic development continues to term in the absence of endogenous, sibling-derived, or maternal Plg. However, $\mathrm{Plg}^{-1}$ mice are predisposed to severe thrombosis, and young animals developed multiple spontaneous thrombotic lesions in liver, stomach, colon, rectum, lung, pancreas, and other tissues. Fibrin deposition in the liver was a uniform finding in 5- to 21-week-old mice, and ulcerated lesions in the gastrointestinal tract and rectal tissue were common. A remarkable finding, considering the well-established linkage between plasmin and the proteolytic activation of plasminogen activators, was that the level of active urokinase-type plasminogen activator in urine was unaffected in $\mathrm{Plg}^{-/}$mice. Therefore, $\mathrm{Plg}$ plays a pivotal role in fibrinolysis and hemostasis but is not essential for urokinase proenzyme activation, development, or growth to sexual maturity.
\end{abstract}

[Key Words: Plasminogen; gene targeting; thrombosis; fertility; proenzyme activation]

Received January 18, 1995; revised version accepted February 27, 1995.

The conversion of plasminogen $(\mathrm{Plg})$ to the active serine protease, plasmin, is controlled by a sophisticated system of proteins that include urokinase-type plasminogen activator ( $\mathrm{uPA})$, tissue-type plasminogen activator (tPA), and an array of Plg-and PA-specific receptors and inhibitors (for reviews, see Danø et al. 1985, 1994; Saksela and Rifkin 1988; Vassalli et al. 1991; Collen and Lijnen 1994). A major driving force for understanding this system of proteins has been the extraordinary number of biological contexts in which plasminogen activation appears to occur (see reviews listed above). In addition to the well-established role of Plg in the proteolytic degradation of fibrin clots (Collen and Lijnen 1994), many indirect observations have suggested that Plg may play an important role in general extracellular proteolysis outside of fibrinolysis. First, at least two physiologically relevant mammalian PAs are known, and only one of them, tPA, has a strong affinity for fibrin (Collen and Lijnen 1994). Second, plasmin can degrade many common extracellular matrix glycoproteins as well as activate latent growth factors (Odekon et al. 1994) and other proenzymes, such as pro-uPA and procollagenase (Werb et al. 1977). Third, the expression of PA, PA inhibitor, and PA

${ }^{4}$ Corresponding author. receptor is highly regulated both in vitro and in vivo and is sensitive to a variety of cytokines, growth factors, hormones and hormone-like agents (Danø et al. 1985; Saksela and Rifkin 1988). Spatially, temporally, and hormonally controlled changes in PA expression have been documented frequently and occur coordinately with processes requiring extracellular matrix breakdown in vivo (Danø et al. 1985; Saksela and Rifkin 1988; Sappino et al. 1989). Fourth, plasminogen activation has been associated with a variety of processes requiring tissue remodeling and/or cell migration, including trophoblast invasion (Sappino et al. 1989), embryonic development (Strickland and Reich 1976; Bode and Dziadek 1979; Valinsky and Reich 1981; Marotti et al. 1982; Sappino et al. 1991; Friedman and Seeds 1994), macrophage migration (Vassalli et al. 1992), ovulation (Sappino et al. 1989), wound healing (Morioka et al. 1987; Pepper et al. 1987; Rømer et al. 1994), angiogenesis (Pepper et al. 1987; Moscatelli et al. 1988), atherosclerosis (Grainger et al. 1994), and tumor cell invasion (Ossowski and Reich 1983; Danø et al. 1985, 1994; Ossowski 1988; Mignatti et al. 1986; Ossowski et al. 1991a,b; Crowley et al. 1993; Kook et al. 1994). Finally, specific inhibitors of PA or PA receptor often have been shown to inhibit cell migration both in vitro and in vivo (Ossowski and Reich 1983; 
Mignatti et al. 1986; Ossowski et al. 1991b; Crowley et al. 1993; Kook et al. 1994).

The recent finding that UPA- and tPA-deficient mice develop and exhibit relatively modest phenotypic abnormalities, other than an age-related risk of thrombosis, suggests that one important role of these PAs is directing fibrinolysis (Carmeliet et al. 1994). However, considerable uncertainty still remains as to the roles of Plg outside fibrinolysis because other PAs of unknown biological significance have been identified, including plasma kallikrein, (Kluft et al. 1987), factor XIIa (Goldsmith et al. 1978), and factor XIa (Mandle and Kaplan 1979). In addition, although Plg disorders are encountered frequently in some populations (Ichinose et al. 1991; Kikuchi et al. 1992), no homozygotes with total Plg deficiency have ever been documented. Finally, potent biological activities have been associated with the noncatalytic portions of $\mathrm{Plg}$, including the angiogenesis- and metastasis-suppressing activity of the Plg derivative, angiostatin, which is made up solely of kringle domains $\left(\mathrm{O}^{\prime}\right.$ Reilly et al. 1994).

To directly establish the role of $\mathrm{Plg}$ and its derivatives in development, hemostasis, reproduction, and tumor cell invasion, we have disrupted the Plg gene in mice. We report that Plg-deficient mice are viable and fertile but experience severe thrombotic problems with an early onset.

\section{Results}

Disruption of the Plg gene

To compromise expression and secretion of all portions of the Plg polypeptide a replacement-type targeting vector was constructed using a combination of $5^{\prime}$-flanking and intron 2 sequences from the cloned murine Plg gene (see Fig. 1A). Incorporation of this targeting vector into the murine genome by homologous recombination results in a 9-kb deletion within the Plg gene that includes proximal promoter sequences, exon 1 (encoding the signal peptide), and exon 2 (encoding 43 residues of the "preactivation peptide"). The targeting vector was introduced by electroporation into the HPRT-deficient embryonic stem (ES) cell line E14TG2a (Hooper et al. 1987) and 2 of 46 stable transfectants picked for analysis were found to have incorporated the transgene by homologous recombination based on both PCR and Southern blot hybridization analysis of genomic DNA extracts (data not shown). Each of these targeted ES cell clones was microinjected into 3.5 -day-old $\mathrm{C} 57 \mathrm{Bl} / 6$ blastocysts to raise chimeric founder transgenic mice. Four of six transgenic males that sired litters passed the mutant Plg gene to their offspring. Crosses of heterozygous mice resulted in the birth of mice that were homozygous for the mutant $\mathrm{Plg}$ gene based on Southern blot analyses of tail biopsy DNA (Fig. 1B). Based on the Mendelian pattern of transgene inheritance, few, if any, Plg-deficient mice were lost in utero. Of 171 progeny derived from heterozygous parents, $43(25 \%)$ were homozygous for the mutant Plg allele $\left(\mathrm{Plg}^{-1-}\right), 83(49 \%)$ were heterozygous $\left(\mathrm{Plg}^{+/-}\right)$, and $45(26 \%)$ were homozygous for the wild-type $\mathrm{Plg}$ allele $\left(\mathrm{Plg}^{++}\right)$.

\section{Homozygous mutant mice do not express detectable Plg mRNA or plasma Plg}

Plg expression is highly liver-specific and a represents a major fraction of total protein secreted into the plasma (Robbins 1992). Therefore, hepatic Plg mRNA was measured by Northern blot hybridization analysis of total RNA extracts from 5-week-old $\mathrm{Plg}^{-1-}, \mathrm{Plg}^{+/-}$, and $\mathrm{Plg}^{+/+}$mice (Fig. 2A). Plg mRNA could be detected easily in RNA preparations from both $\mathrm{Plg}^{+/+}$and $\mathrm{Plg}^{+/-}$ mice. The mRNA levels in $\mathrm{Plg}^{+/-}$livers were approximately half that of $\mathrm{Plg}^{+1+}$ livers based on quantitative PhosphorImager analysis (data not shown). However, no hybridizing transcript of the size of Plg mRNA could be detected in $\mathrm{Plg}^{-/}$-derived liver RNA samples when analyzed in parallel (Fig. 2A). Even very long exposures of blots to PhosphorImaging screens indicated little hybridizing material throughout the $\mathrm{Plg}^{-1-}$ RNA lane. Based on the sensitivity of the PhosphorImaging system in detecting Plg mRNA in control liver samples, the level of any hepatic $\mathrm{Plg}$ transcripts derived from the mutant $\mathrm{Plg}$ gene was estimated to be at least 3000-fold less than the Plg mRNA level found in control livers. In addition, no Plg transcripts could be detected in either RNA extracts from adult brain, heart, spleen, lung, and kidney or RNA extracts from entire $\mathrm{Plg}^{-1-}$ newborns, suggesting that there are no secondary sites of expression of the mutant $\mathrm{Plg}$ gene in $\mathrm{Plg}^{-1-}$ mice (Fig. 2B).

Plg enzymatic activity was analyzed in whole plasma by using a gel zymography assay. In this assay system, the caseinolytic activity of plasmin is detected after electrophoretic separation of plasma proteins by SDS-gel electrophoresis. The Plg zymography assay is very sensitive and offers the advantage that the many plasmin inhibitors found in plasma [i.e., $\alpha 1$-antitrypsin $(54 \mathrm{kD})$, $\alpha 2$-antiplasmin $(70 \mathrm{kD})$, and $\alpha 2$-macroglobulin $(725 \mathrm{kD})]$ are electrophoretically separated from $\mathrm{Plg}(92 \mathrm{kD})$ prior to activity detection. A plasminogen activator-stimulated caseinolytic activity with an apparent molecular weight identical to $\mathrm{Plg}$ was readily detectable in whole plasma collected from $\mathrm{Plg}^{+/+}$and $\mathrm{Plg}^{+/-}$mice (Fig. 3A). This caseinolytic activity appears to be plasmin(ogen)mediated based on the diminished activity in parallel zymography gels that were cast without PA. In contrast, no PA-stimulated caseinolytic activity was observed in whole plasma samples from $\mathrm{Plg}^{-1}$ mice (Fig. 3A). Given that Plg activity could be detected in $\mathrm{Plg}^{+1+}$-derived samples containing as little as $8 \mathrm{nl}$ of plasma, and no PA-activatable caseinolytic activity could be detected in as much as $5 \mu \mathrm{l}$ of plasma from $\mathrm{Plg}^{-1-}$ mice, these data indicate that any plasma $\mathrm{Plg}$ activity in the $\mathrm{Plg}^{-/-}$ mice must be at least 600 -fold less than $\mathrm{Plg}^{+/+}$mice. The well-known affinity of $\mathrm{Plg}$ for lysine-Sepharose (Deutsch and Mertz 1970) was also exploited to establish whether any residual Plg antigen could be detected in plasma collected from $\mathrm{Plg}^{-1}-$ mice. Although plasma fractions eluted from lysine-Sepharose with the lysine 
Bugge et al.

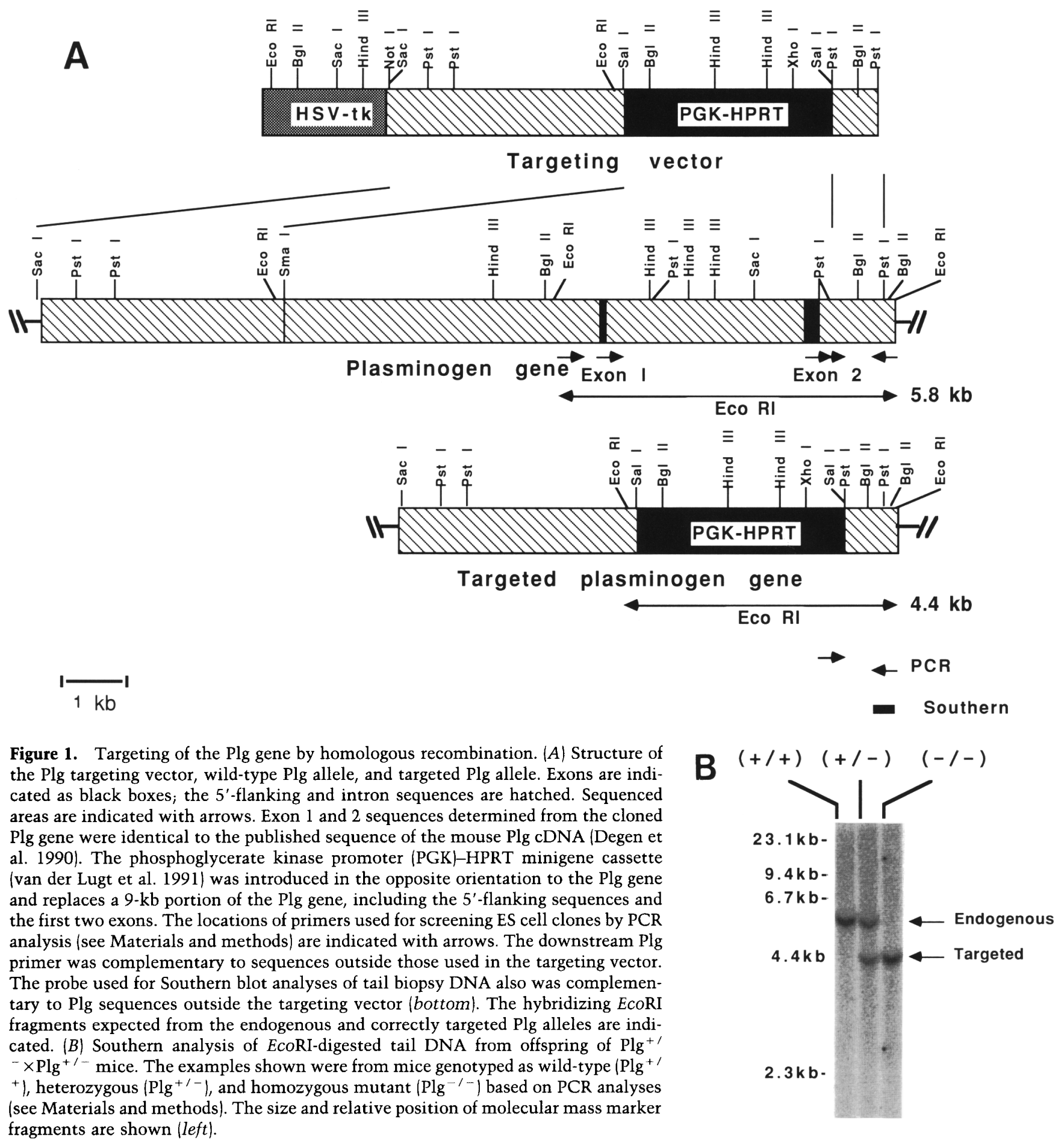
fragments are shown (left).

analog, $\epsilon$-amino caproic acid, were markedly enriched for $\mathrm{Plg}$ antigen in samples from $\mathrm{Plg}^{+/+}$mice, no $\mathrm{Plg}$ antigen was detected in Western blot analyses of lysine-Sepharose eluates or whole plasma from $\mathrm{Plg}^{-1-}$ mice (Fig. 3B). Based on the sensitivity of the Western blot assay for $\mathrm{Plg}$ antigen, $\mathrm{Plg}$ levels in plasma samples from $\mathrm{Plg}^{-1-}$ mice were, again, more than two orders of magnitude below those in $\mathrm{Plg}^{+1+}$ mice. Thus, the deletion introduced in the endogenous Plg gene appears to eliminate Plg gene transcription and gives rise to a Plg-null phenotype.

\section{Hematological parameters in Plg-deficient mice}

The loss of plasma Plg does not have any significant impact on general hematological parameters when measured in 4- to 5-week-old mice. In particular, no major 


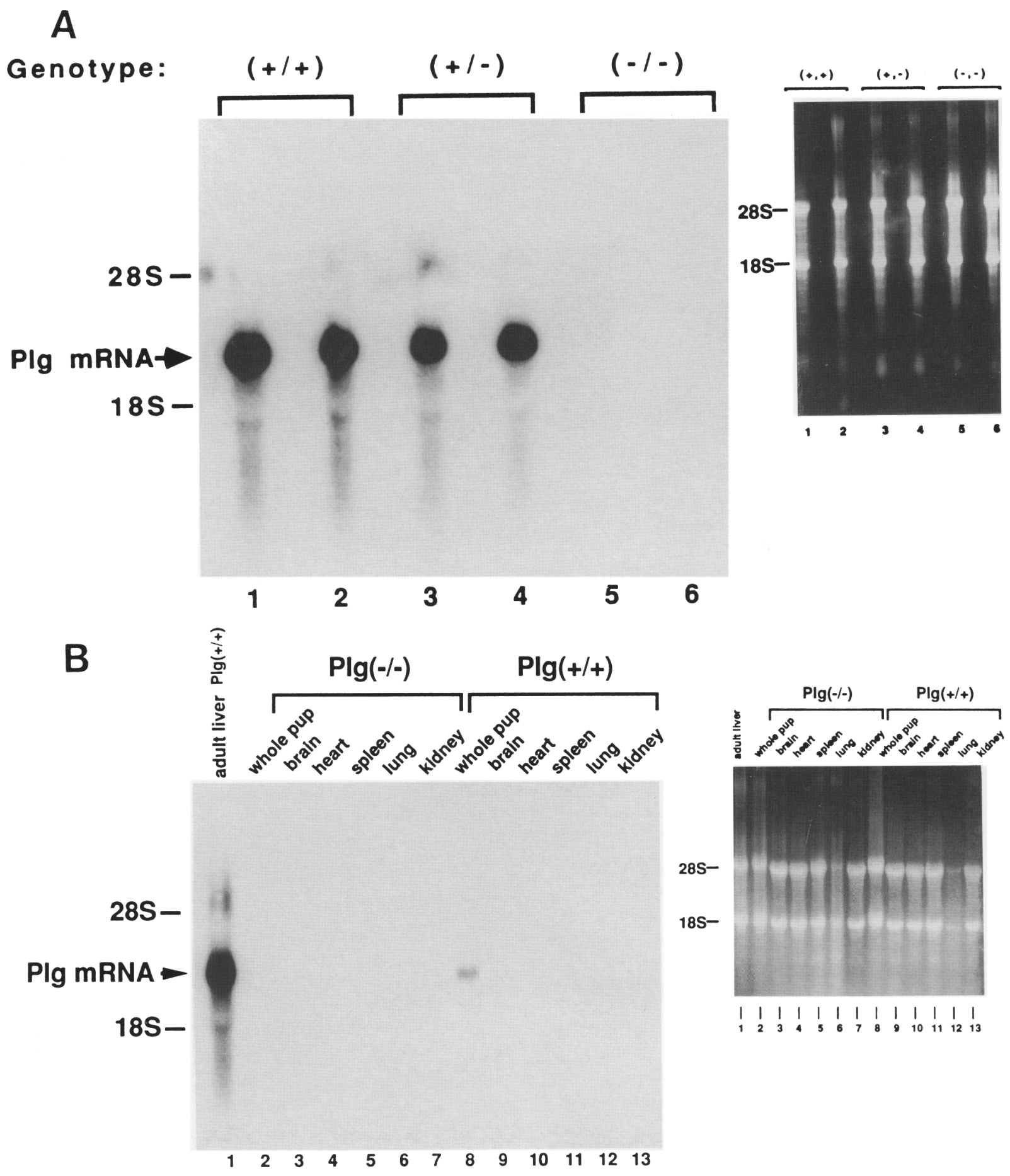

Figure 2. Absence of detectable Plg mRNA in mice homozygous for the targeted Plg allele. $(A)$ Northern blot of total liver RNA from two wild-type mice (lanes 1,2), two heterozygous mice (lanes 3,4), and two mice homozygous for the targeted allele (lanes 5,6). Positions of $28 \mathrm{~S}$ and $18 \mathrm{~S}$ rRNAs are indicated. Ethidium bromide staining of the agarose gel prior to blotting (right) indicated similar RNA loading in all cases. $(B)$ Northern blot of total RNA extracted from various tissues collected from 4-week-old Plg ${ }^{-1-}(1 \mathrm{lanes} 3-7)$ and $\mathrm{Plg}^{+\prime+}$ (lanes 9-13) mice, and from whole newborn $\mathrm{Plg}^{-1-}$ (lane 2), and $\mathrm{Plg}^{+1+}$ (lane 8) mice. Brain (lanes 3,9), heart (lanes 4,10), spleen (lanes 5,11), lung (lanes 6,12), and kidney (lanes 7,13). Total liver RNA isolate from an adult Plg ${ }^{+1+}$ mouse was analyzed in parallel as a positive control. Similar amounts of RNA were loaded as indicated by the ethidium bromide-stained gel (right).

differences were found between control and $\mathrm{Plg}^{-1-}$ mice with regard to platelet counts, red and white cell counts, and hematocrit (Table 1). In addition, no differences were found in plasma levels of uPA or tPA based on gel zymography of whole plasma (data not shown). Furthermore, thrombin time measurements (Table 1) and pre- 
A
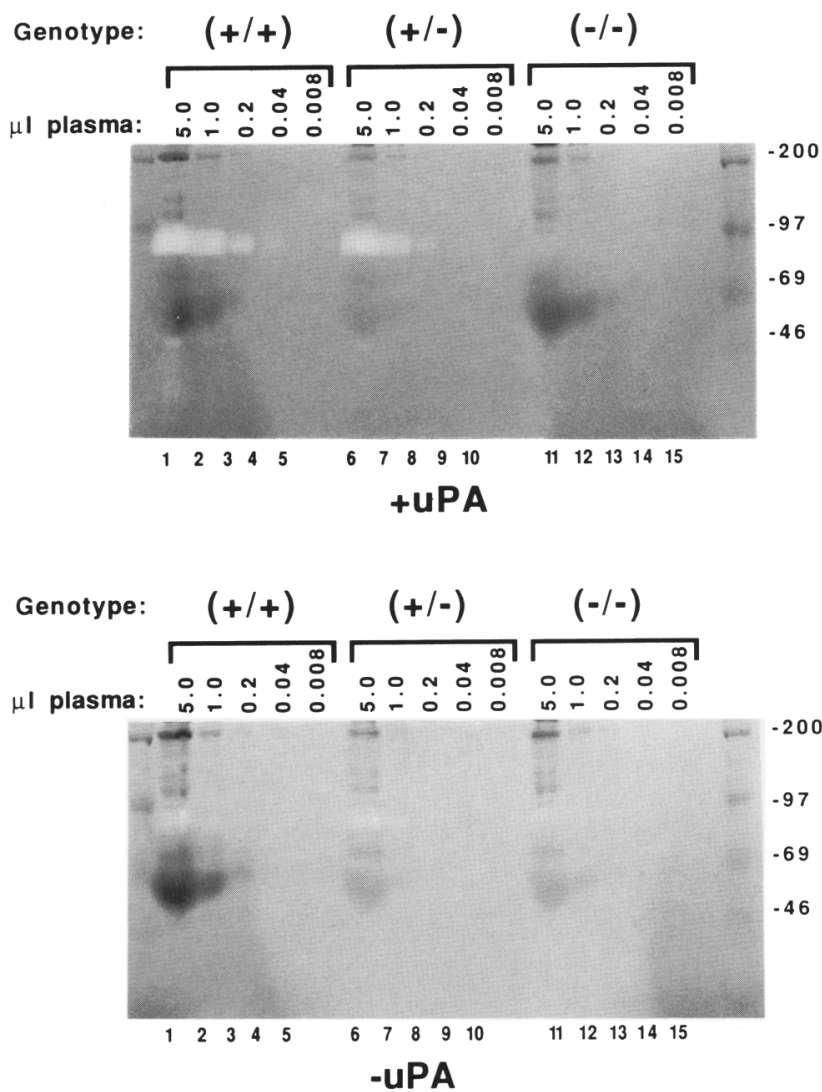

00

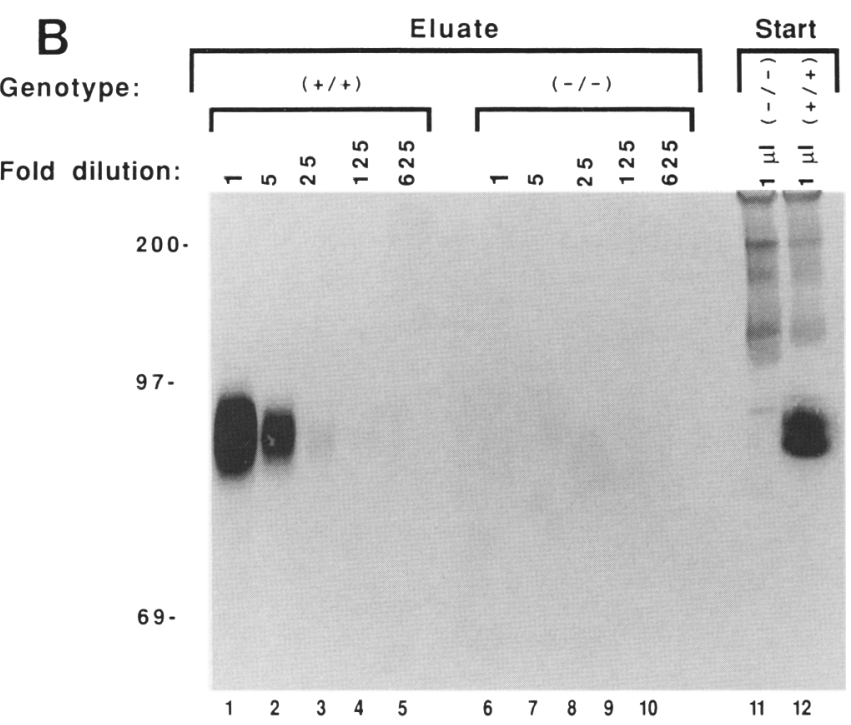

Figure 3. Absence of Plg activity and antigen in plasma of Plg-targeted mice. (A) Gel zymography of fivefold serial dilutions of plasma from $\mathrm{Plg}^{+1+}$ mice (lanes 1-5), $\mathrm{Plg}^{+/-}$mice (lanes $\left.6-10\right)$, and $\mathrm{Plg}^{-1}$ mice (lanes 11-15). Gels were cast with (top) and without (bottom) $20 \mathrm{IU} / \mathrm{ml}$ of human uPA. (B) Immunoblot analysis of $\mathrm{Plg}^{-1-}$-derived whole plasma $(1 \mu \mathrm{l}$, lane 11$), \mathrm{Plg}^{+1+}$-derived whole plasma, $\{1$ $\mu l$, lane 12$)$, and fivefold serial dilutions of plasma fractions eluted from lysine-Sepharose $\left(\mathrm{Plg}^{+1+}\right.$ eluate, lanes $1-5$; $\mathrm{Plg}-1-\mathrm{eluate}^{-}$ lanes $6-10)$. Plg was detected using a polyclonal antibody raised against rat plasminogen as described in Materials and methods. The relative sizes and the positions of protein molecular mass standards are indicated.

liminary measurements using a fibrinogen-specific enzyme-linked immunosorbent assay (ELISA) (K. Holmbäck and T. Bugge, unpubl.) indicated that plasma fibrinogen levels in $\mathrm{Plg}^{-1-}$ and $\mathrm{Plg}^{+1+}$ mice were comparable. Thus, Plg deficiency per se does not result in appreciable anemia, thrombocytopenia, or change in steady-state fibrinogen levels. However, it remains to be established whether older mice that develop fibrin deposition in tissues (see below) also develop secondary alterations in these hematological parameters.

Proteolytic activation of $u P A$ in urine of Plgdeficient mice

Plasmin is generally thought to have a physiologically important positive feedback on plasminogen activation by converting inactive, single-chain pro-uPA to active, two-chain uPA. However, the factors that contribute to initial pro-uPA activation and plasmin formation are unclear (Ichinose et al. 1986; Kobayashi 1991). The urine is a rich source of uPA, and a large fraction is two-chain
uPA in normal animals (Kielberg et al. 1985; Sappino et al. 1991). To determine whether Plg contributes signifi-

Table 1. Hematological analysis of Plg-deficient transgenic mice

\begin{tabular}{lcc}
\hline & $\mathrm{Plg}^{+/+}$mice & $\mathrm{Plg}^{-1-}$ mice \\
\hline Blood analysis & & \\
platelets $\left(\times 10^{9} /\right.$ liter $)$ & $979 \pm 130(3)$ & $953 \pm 48(4)$ \\
RBC $\left(\times 10^{12} /\right.$ liter $)$ & $7.5 \pm 0.7(3)$ & $7.3 \pm 06(4)$ \\
WBC $\left(\times 10^{9} /\right.$ liter $)$ & $2.6 \pm 1.3(3)$ & $2.9 \pm 0.9(4)$ \\
hematocrit $(\%)$ & $40.1 \pm 1.3(3)$ & $44.3 \pm 3.2(4)$ \\
hemoglobin (grams $/ \%)$ & $12.3 \pm 0.5(3)$ & $13.1 \pm 1.3(4)$ \\
$\quad$ Plasma thrombin time & $13.1 \pm 1$ & $13 \pm 2$ \\
& $\sec (3)$ & $\sec (4)$ \\
\hline
\end{tabular}

Data presented is the mean \pm S.D. with the number of mice analyzed shown in parentheses. All mice analyzed were 4-5 weeks of age. Control wild-type mice were adult Black Swiss. ${ }^{a}$ Thrombin times were measured in reaction mixtures containing equal volumes of plasma and $20 \mathrm{U} / \mathrm{ml}$ of bovine thrombin in PBS. 
cantly to the formation of this two-chain uPA in the urogenital tract, urine from $\mathrm{Plg}^{-1-}$ and $\mathrm{Plg}^{+/+}$mice was compared using esterase and zymography activity assays and Western blot immunoassay. Urine samples were also collected from $\mathrm{uPA}^{-/-}$mice (Carmeliet et al. 1994) to control for the specificity of each assay. Surprisingly, the enzymatic activity of uPA in urine collected from $\mathrm{Plg}^{-1-}$ and $\mathrm{Plg}^{+/+}$mice was similar (Fig. 4A; data not shown). Furthermore, the proportion of high molecular weight $(45,000)$ and low molecular weight $(30,000)$ uPA measured by gel zymography and immunoblot of nonreduced samples was similar between normal and Plg-deficient animals (Fig. 4B,C). While these assays in-
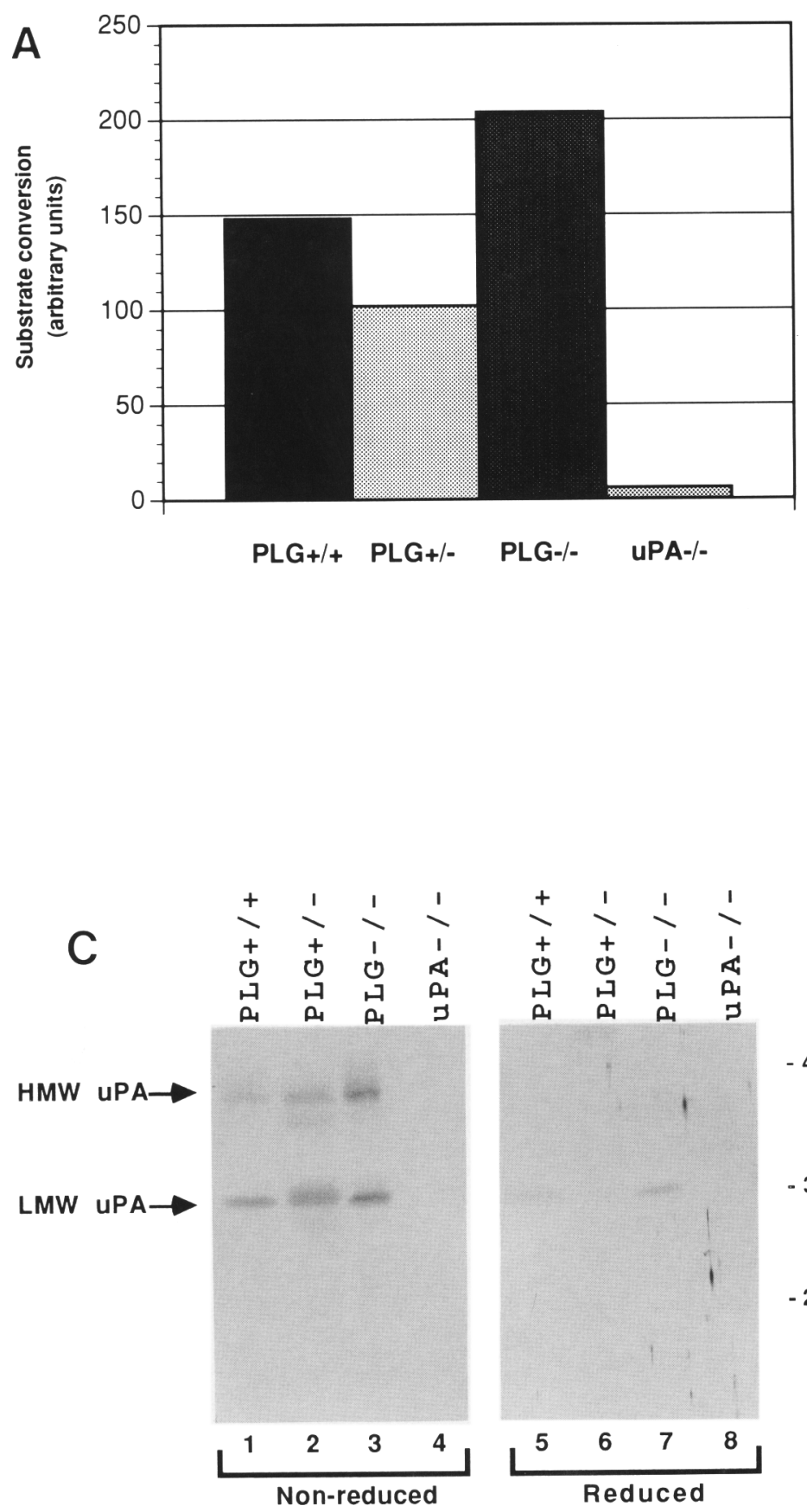

dicate that the generation of low molecular weight uPA in the urogenital tract is not dependent on plasmin, they do not indicate the fraction of high molecular weight uPA initially present in a two-chain form. This question was addressed by immunoblot assay of reduced samples. In samples from both control mice and $\mathrm{Plg}^{-1-}$ mice, reduced 45,000 high molecular weight uPA was largely separated into 30,000 heavy chain (Fig. 4C, right; data not shown) and 15,000 light chain (immunologically not detected; Kielberg et al. 1985) fragments. Therefore, at least in the urogenital system, plasmin does not appear to be essential for the conversion of pro-uPA to enzymatically active forms of uPA.

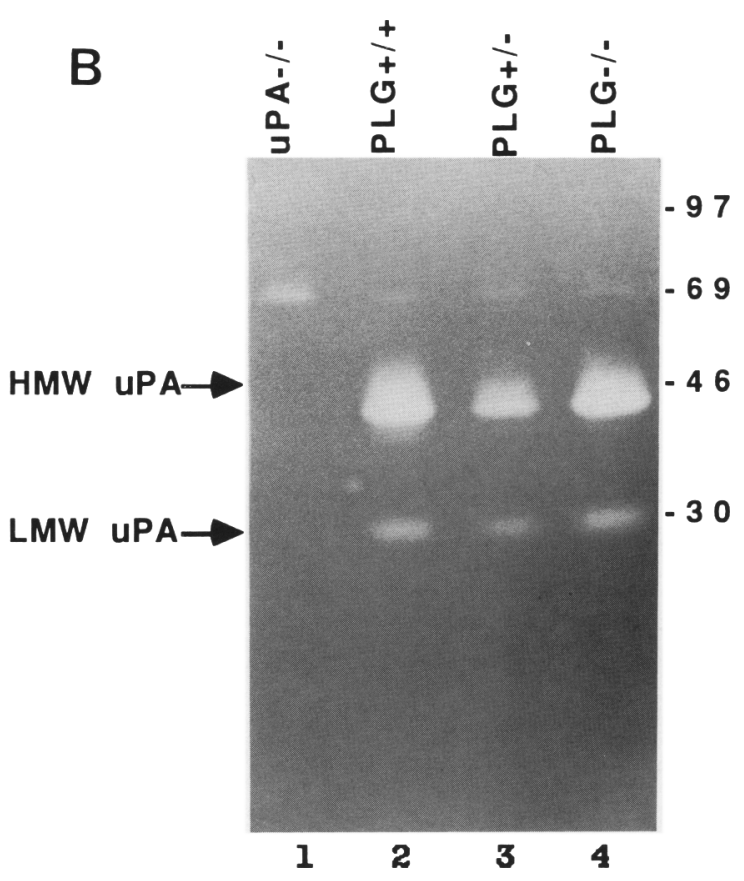

Figure 4. Enzymatically active two-chain uPA in Plg-deficient mice. (A) uPA-specific esterase activity in representative bladder urine samples collected from $\mathrm{Plg}^{+/+}, \mathrm{Plg}^{+/-}$, and $\mathrm{Plg}^{-1-}$ mice. Bladder urine from a uPA ${ }^{-1-}$ mouse was assayed in parallel to establish assay specificity. (B) uPA activity detected by gel zymography of representative bladder urine samples $\left(1 \mu \mathrm{l}\right.$ analyzed) collected from $\mathrm{Plg}^{+1+}$ (lane 2), $\mathrm{Plg}^{+1-}$ (lane 3), and $\mathrm{Plg}^{-1-}$ (lane 4) mice. Bladder urine from a $\mathrm{uPA}^{-1-}$ mouse was analyzed in parallel (lane 1) to control for assay specificity. (C) Immunoblot detection of UPA in nonreduced (lanes 1-4) and reduced (lanes 5-8) bladder urine samples $(5 \mu 1$ analyzed) collected from $\mathrm{Plg}^{+1+}$ (lanes 1,5), $\mathrm{Plg}^{+/-}$(lanes $2,6)$, and $\mathrm{Plg}^{-1-}$ mice (lanes 3,7). Bladder urine from a $\mathrm{uPA}^{-1-}$ mouse was analyzed in parallel to control for

-21.5 specificity (lanes 4,8 ). Similar results were obtained in three independent experiments with bladder and void urine sample sets collected from $\mathrm{Plg}^{+/+}, \mathrm{Plg}^{+/-}$, $\mathrm{Plg}^{-1-}$, and $\mathrm{uPA}^{-1-}$ mice using all three assays /data not shown). The relative sizes and positions of protein molecular weight standards are indicated at right. (HMW uPA) High molecular weight uPA; (LMW) low molecular weight uPA. 
Bugge et al.

\section{Survival and fertility in PIg-deficient mice}

Forty-three $\mathrm{Plg}^{-1-}$ mice have now been maintained for up to 21 weeks with no obvious phenotypic abnormalities observed in the majority of animals. However, inflammatory rectal lesions were found in $7 \mathrm{Plg}^{-1-}$ mice lone at 5 weeks, two at 9 weeks, three at 13-14 weeks, and one at 21 weeks of age), possibly secondary to fibrin deposition and vasoocclusion (see below). A rectal prolapse was observed in the oldest of these mice. Two 8- to 9-week-old mice were found to have penile lesions. With the exception of these nine mice, no differences have been observed between $\mathrm{Plg}^{-1-}$ mice and littermate controls with regard to either outward appearance, behavior, weight gain, or survival characteristics (data not shown). Neither runting nor premature death was evident in the 5 -month window examined that extends well into adulthood. Furthermore, $\mathrm{Plg}^{-1-}$ mice are fertile, with males siring multiple litters and females carrying their litters to term. Seven litters have been raised in test crosses between $\mathrm{Plg}^{-1-}$ males and $\mathrm{Plg}{ }^{+/+}$females, and four litters have been raised between $\mathrm{Plg}^{+/+}$males and $\mathrm{Plg}^{-1-}$ females. The average litter sizes in these test crosses were 7.6 and 7.8 pups, respectively. These values are comparable to the average litter size of 8.1 recorded with control breeding pairs in our colony. Two test crosses between mates both genotyped as Plg-null were also productive, with four and five $\mathrm{Plg}^{-1-}$ mice born. The generation of offspring from $\mathrm{Plg}^{-1-}$ parents is particularly significant in that it demonstrates clearly that Plg is not essential for development to term; the developing offspring from crosses of this type have no access to either endogenous or exogenous (maternal- or sibling-derived) Plg.

\section{Pathological consequences of Plg deficiency}

Five $\mathrm{Plg}^{-/-}$mice with overt rectal lesions (see above) and 12 apparently healthy $\mathrm{Plg}^{-/-}$mice, including five juvenile animals (5-7 weeks old) and seven young adults (10-17 weeks old), were sacrificed for a detailed histological examination of tissues. Age-matched $\mathrm{Plg}^{+/-}$and $\mathrm{Plg}^{+1+}$ mice were analyzed in parallel as controls. A uniform feature in all $17 \mathrm{Plg}^{-1-}$ mice examined microscopically was the presence of multiple hepatic fibrin deposits that were recognized as fibrillar material in hematoxylin/eosin-stained sections (Fig. 5B-D) that immunolabeled intensely using a polyclonal antibody raised against mouse fibrinogen (Fig. 5E,F). These deposits showed varying degrees of organization with infiltration of spindle cells, possibly macrophages or fibroblasts (Fig. 5D). Necrosis was apparent within adjacent tissue in only a fraction of the hepatic lesions, suggesting that these deposits were generally not extensive enough to impair perfusion in these young mice. Although these deposits were found throughout the liver, they tended to be more numerous in the subcapsular region, possibly because of surface trauma (for examples, see Fig. 5, D and F). In addition, the lesions were more extensive in terms of number, size, and degree of adjacent necrosis in the older mice examined. No such deposits were found in either hematoxylin/eosin-stained (Fig. 5A) or anti-fibrinogen-immunostained (Fig. 5G; data not shown) livers collected from age-matched control mice.

Other sites of fibrin deposition and organ damage were also common in $\mathrm{Plg}^{-1-}$ mice. Microscopic analysis of rectal tissues from $\mathrm{Plg}^{-1-}$ mice with visible rectal lesions uniformly revealed anal-rectal tissue ulceration with surface exudate (mixture of necrotic debris, neutrophils, and bacteria) and surrounding fibrin deposition (e.g., see Fig. 6A,B). However, similar lesions were also discovered in four animals without gross rectal lesions (data not shown), implying that fibrin deposition and necrosis may precede and predispose to ulceration. Gastric ulcers were seen in 10 of the $17 \mathrm{Plg}^{-1-}$ mice examined (ranging from 5 to 21 weeks of age), including 7 mice with ulcerated lesions in the glandular portion of the stomach (e.g., see Fig. 6C,D), 2 with an ulcer in the squamous portion of the stomach (e.g., see Fig. 6E), and 1 with an ulcer at the junction of the two portions /data not shown). Colonic ulcers, proximal to the rectum, were seen in three $\mathrm{Plg}^{-1-}$ mice $(7$ and 10 weeks of age) (data not shown). In each of these lesions, the surface epithelium was necrotic and covered by exudate, the underlying tissue was necrotic with diffuse fibrin deposition in and around the lesions, and the adjacent mucosa was reactively altered with epithelial hyperplasia and intravascular fibrin deposition in the lamina propria. The appearance of these ulcers is consistent with ischemic necrosis secondary to fibrin occlusion of small vessels. Seven mice (10-21 weeks old) showed pulmonary lesions, with capillary fibrin thrombi in four mice and organizing patches of alveolar fibrin in four animals (e.g., see Fig. $6 \mathrm{~F}$ ). In one 11-week-old mouse, organizing fibrin deposits were observed in multiple pancreatic lobules (Fig. 6G), with one centrally located lesion associated with lobule necrosis (data not shown). Fibrin deposits were detected in the thymus of one 5-week-old animal and in the adrenal tissue of one 14-week-old animal (Fig. $6 \mathrm{H})$. Finally, the ovary of a 14-week-old female had fibrin deposits in small vessels, and the uteri of three females housed with males contained large aggregates of fibrin, possibly remnants of earlier or involuting pregnancies (data not shown). Brain, heart, spleen, small intestine, kidney, testicle, bone, muscle, tongue, oropharynx, and miscellaneous connective tissue were also surveyed, and no lesions were detected.

\section{Discussion}

The studies presented here provide direct evidence that $\mathrm{Plg}$ and its proteolytic derivatives, plasmin and angiostatin, are not essential for either mouse development, growth, or fertility. Each of these processes was unimpeded under conditions where no trace of residual Plg could be detected within a sensitivity range extending nearly three orders of magnitude below normal. Notably, any Plg available at this level would be of little biological significance given that the expected Plg concentrations would fall many orders of magnitude below the $2 \mu \mathrm{M} K_{\mathrm{m}}$ 


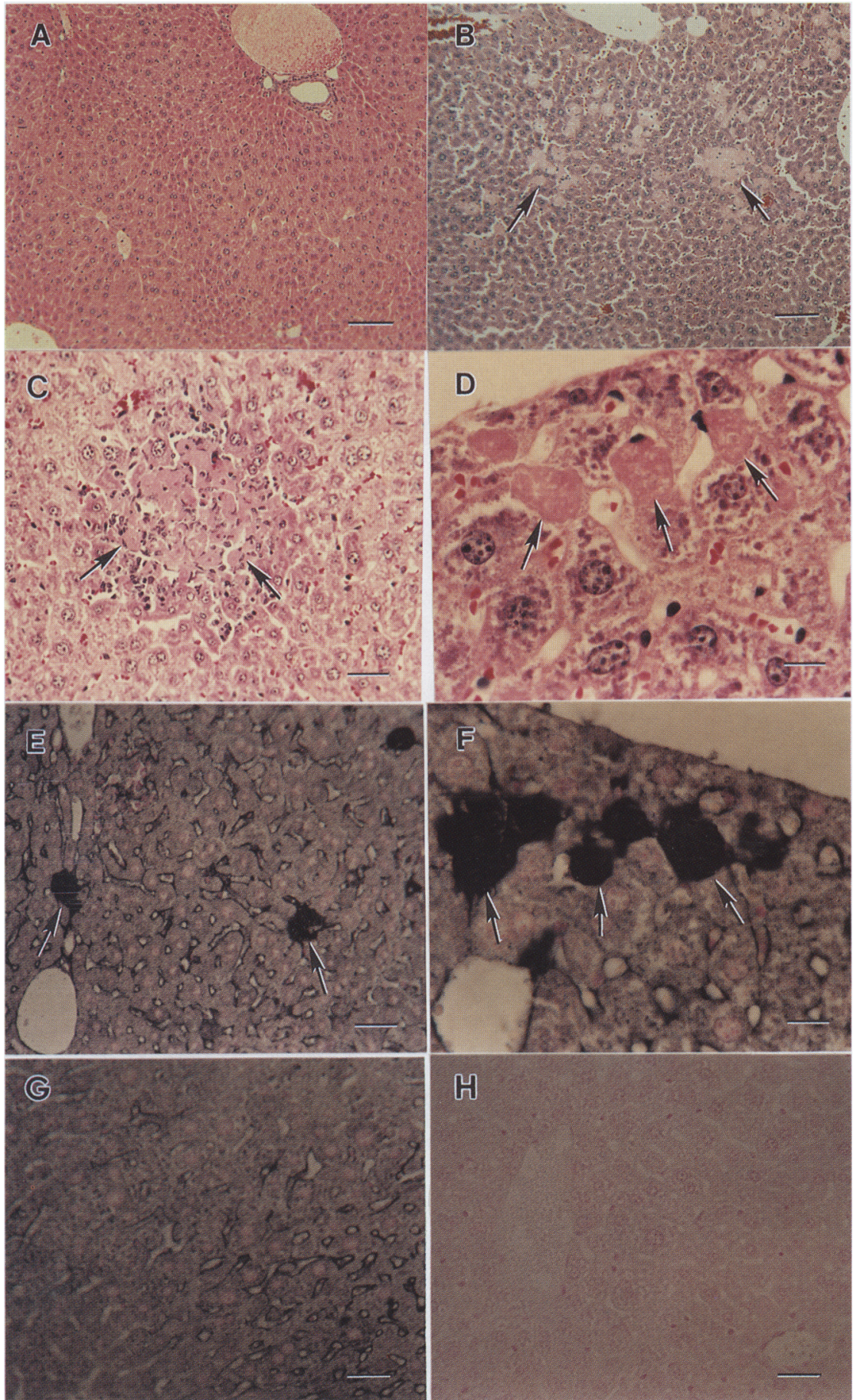

Figure 5. Fibrin deposition in livers of Plg-deficient mice. (A) Hematoxylin/ eosin-stained liver section from a control, $\mathrm{Plg}^{+1+}$ mouse. Magnification bar, 100 $\mu \mathrm{m}$. (B) Hepatic fibrin deposits (arrows) in the liver of an 8-week-old $\mathrm{Plg}^{-/-}$mouse. Large fibrin patches contain necrotic hepatocytes. Magnification bar, $100 \mu \mathrm{m}$. (C) Fibrin deposition in the liver of a 10-weekold $\mathrm{Plg}^{-/-}$mouse with entrapped hepatocytes and infiltration of spindle cells (arrows) indicating early organization. Magnification bar, $35 \mu \mathrm{m}$. (D) Hepatic fibrin deposition in subcapsular sinusoids (arrows) of an 11-week-old $\mathrm{Plg}^{-1-}$ mouse. Magnification bar, $1.5 \mu \mathrm{m}$. (E) Immunoperoxidase-stained sinusoidal fibrin(ogen) in a liver section from a 10-week-old $\mathrm{Plg}^{-1-}$ mouse. The deposits (arrows) were rounded and scattered throughout the parenchyma. Magnification bar, $35 \mu \mathrm{m} .(F)$ Higher magnification of immunostained sinusoidal fibrin deposits (arrows) in a subcapsular region similar to that illustrated in $D$. Magnification bar, $1.5 \mu \mathrm{m}$. $(G) \mathrm{Im}$ munostain of fibrin(ogen) in a liver section from a control, 10-week-old $\mathrm{Plg}^{+/-}$mouse indicating the normal sinusoidal staining pattern and the lack of lumenal accumulation. Magnification bar, $35 \mu \mathrm{m}$. $(H)$ Liver section from a $\mathrm{Plg}^{-1-}$ mouse treated with preimmune serum prior to immunoperoxidase labeling. for PAs when bound to either fibrin or the cell surface (Ellis and Danø 1992; Collen and Lijnen 1994). Thus, Plg-mediated proteolysis either plays no fundamental role in developmental cell migration and tissue remodeling events or other extracellular proteolytic systems can fully compensate for the loss of Plg. Although a surprising number of partial functional overlaps between related proteins have been identified by using gene tar- geting (for examples, see Lohnes et al. 1993; Rudnicki et al. 1993; Carmeliet et al. 1994), no other secretory protease of similar specificity and abundance in the circulation stands out as a possible compensatory enzyme. The results reported here strongly imply that all facets of plasmin-mediated proteolysis, including degradation of extracellular matrices, and activation of proenzymes and latent growth factors, are not strictly needed for ovula- 
Bugge et al.

Figure 6. Fibrin deposition in other organs of Plg-deficient mice. $|A|$ Longitudinal section of the rectum at the squamocolumnar junction in a 14-week-old $\mathrm{Plg}^{-} /^{-}$mouse showing fibrin deposition and ulceration (arrows) with surface exudate and reactive hyperplasia (asterisk). Magnification bar, $350 \mu \mathrm{m}$. (B) Higher magnification of $A$ showing fibrin deposition and surface ulceration. Magnification bar, $100 \mu \mathrm{m}$. (C) Ulceration in the glandular portion of the stomach (arrows) of a 14-week-old mouse. Magnification bar, $350 \mu \mathrm{m}$. (D) Higher magnification of $C$ showing capillary fibrin deposition (arrows) at the base of the ulcer. Magnification bar, $35 \mu \mathrm{m}$. $(E)$ Ulceration in the upper portion of the stomach of a 11week-old mouse with reactive hyperplasia in the adjacent squamous mucosa (asterisks). Note fibrin deposition at the base of the ulcer (arrow). Magnification bar, 350 $\mu \mathrm{m} .(F)$ Fibrin deposition (arrows) in an area of organization in the lung of a 10-week-old mouse. Magnification bar, $35 \mu \mathrm{m}$. (G) Fibrin deposition in the periacinar capillaries of the pancreas (arrows) of an 11-week-old mouse. The ingrowth of spindle cells indicates early organization. Magnification bar, $100 \mu \mathrm{m}$. $(H)$ Interstitial fibrin deposition (arrows) in thymus outlining areas of thymocyte dropout. Magnification bar, 100 $\mu \mathrm{m}$.
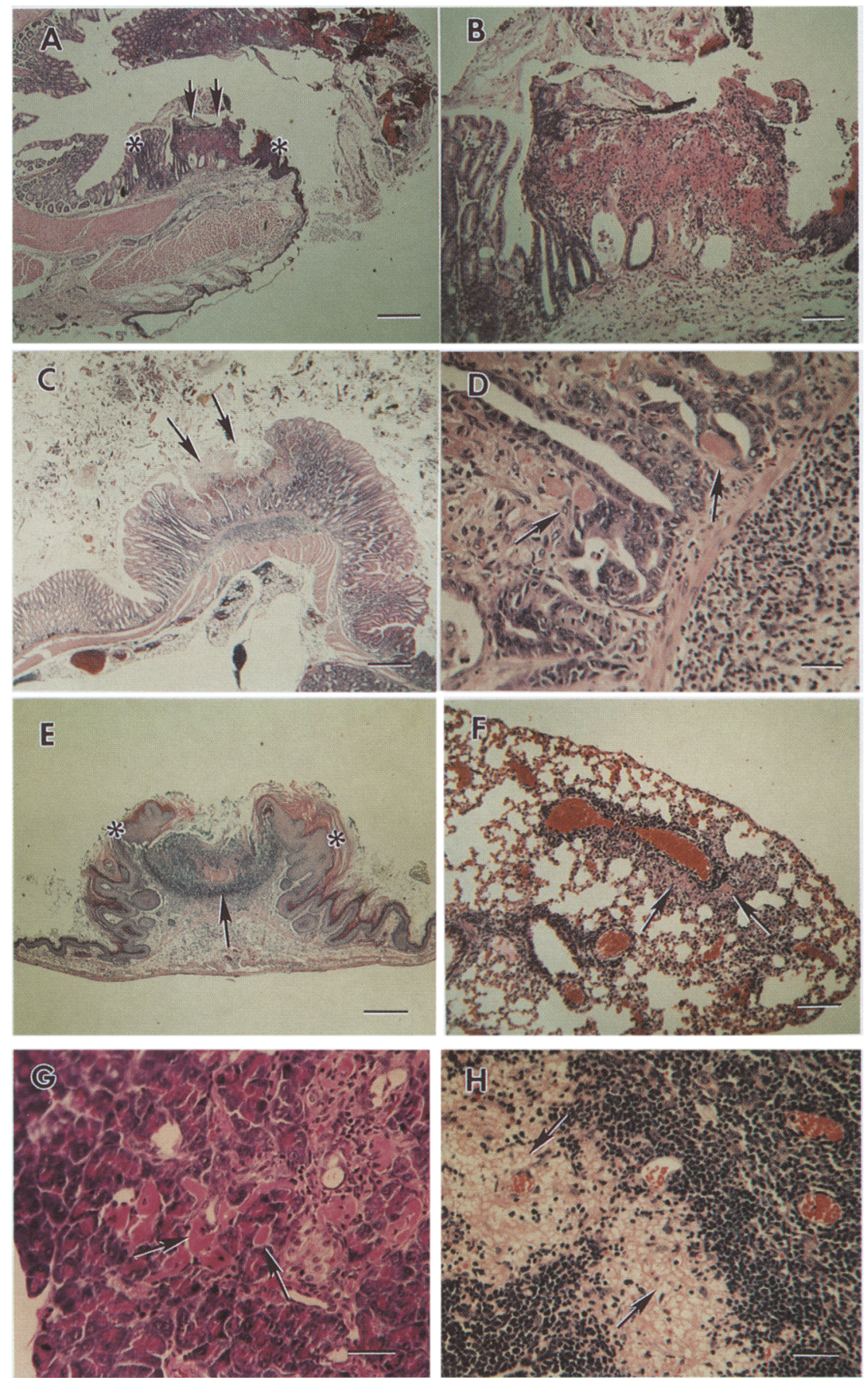

tion, spermatogenesis, embryogenesis, or growth to sexual maturity. However, subtle alterations in development or behavior, and a reduction in fertility in multiparous females, cannot be excluded based on the available data. The finding of fibrin deposits in the ovary and uterus of mice suggests that fertility may become impaired as $\mathrm{Plg}^{-1-}$ females age.

A histological survey of tissue collected from juvenile and young adult $\mathrm{Plg}^{-1-}$ mice provides an indication that severe thrombosis, vascular occlusions, and widespread organ damage is a common feature of $\mathrm{Plg}^{-1-}$ mice. The general predisposition to thrombosis documented here in $\mathrm{Plg}^{-1-}$ mice is reminiscent of the phenotype found in PA-deficient $\left(\mathrm{PA}^{-1-}\right)$ mice (Carmeliet et al. 1994) but with some notable differences. First, the various histological abnormalities in $\mathrm{PA}^{-1-}$ mice were only seen in animals older than 2-3 months of age and most significantly in ill, "preterminal" mice. In contrast, the $\mathrm{Plg}^{-1-}$ mice uniformly develop hepatic fibrin deposits by 5 weeks of age, and several of these recently weaned mice 
had thrombotic ulcerations in the stomach and rectal tissue as well as other thrombotic lesions. Second, stomach ulcers were found in more than half of the $\mathrm{Plg}^{-1-}$ mice examined, but neither this nor thrombotic lesions in the pancreas, thymus, or adrenal tissue were described in $\mathrm{PA}^{-1-}$ mice. Finally, fibrin deposits were documented in kidney, skin, ear, and small intestines of $\mathrm{PA}^{-1-}$ mice, whereas these tissues were apparently free of fibrin deposits in the 5- to 21 -week-old $\mathrm{Plg}^{-1-}$ mice examined. Some of these differences may be related to differences in genetic background, the variable penetrance of specific thrombotic events in both $\mathrm{PA}^{-1-}$ and $\mathrm{Plg}^{-1-}$ lines, and/or the youth and overall good health of the $\mathrm{Plg}^{-1-}$ mice that have been collected so far for histological analysis. However, it cannot be excluded at present that any phenotypic differences between $\mathrm{PA}^{-1-}$ and $\mathrm{Plg}^{-1-}$ mice may be related to the availability of alternative Plg activators or to noncatalytic functions of Plg in uPA- and tPA-deficient mice. The long-term impact of Plg deficiency on thrombotic complications and life span remains to be determined.

The development of fibrin deposits in $\mathrm{Plg}^{-1-}$ mice is consistent with the severe thrombotic problems reported in patients identified with dysplasminogenemia (Aoki et al. 1978; Ichinose et al. 1991; Kikuchi et al. 1992; Robbins 1992; Azuma et al. 1993) and hypoplasminogenemia (Lottenberg et al. 1985; Girolami et al. 1986; Mannucci et al. 1986; Dolan et al. 1988; Patrassi et al. 1993), which include recurring venous thrombosis, pulmonary hypertension, retinopathy, and stroke. However, the total deficit of Plg established in transgenic mice is distinct from any known Plg disorder in human patients. Interestingly, simple heterozygosity for either Plg deficiency (with half-normal Plg activity and antigen) or dysplasminogenemia (with half-normal Plg activity but normal antigen) appears to be associated with thrombotic tendency requiring clinical treatment. However, other factors, such as infection, injury, or vascular disease, are likely to contribute to this tendency, as only a subset of heterozygotes, even within the same family, suffer from thrombosis (Aoki et al. 1978; Girolami et al. 1986; Dolan et al. 1988; Kikuchi et al. 1992; Robbins 1992; Azuma et al. 1993; Patrassi et al. 1993). Remarkably, one form of dysplasminogenemia (type-1, $\mathrm{Ala}^{601} \rightarrow \mathrm{Thr}$ ) occurs with an estimated gene frequency of $\sim 2 \%$ in the Japanese population (Kikuchi et al. 1992), but few homozygous patients $(\sim 10 \%$ residual activity; Aoki et al. 1978) have ever been identified (Aoki et al. 1978; Ichinose et al. 1991; Kikuchi et al. 1992). Our finding that a more severe form of Plg deficiency is compatible with life suggests that the expected 50,000 (presumably asymptomatic) homozygotes for type-1 dysplasminogenemia might exist among the 125 million Japanese.

Although the multiple sites of fibrin deposition observed in $\mathrm{Plg}^{-1-}$ mice might result from a primary defect in tissue development and architecture, no obvious alterations have been found under either gross or microscopic examination. Therefore, one hypothesis that emerges from this study is that the fundamental, and possibly only essential, physiological role of the Plg ac- tivation system is fibrinolysis. The finding that uPA and tPA functionally complement each other in vivo (Carmeliet et al. 1994) is consistent with this general notion. uPA may primarily participate in cell-associated fibrinolysis via its interactions with the high-affinity uPA receptor (Vassalli et al. 1991), and tPA may mediate cellindependent and cell-associated clot lysis via its fibrin binding (Collen and Lijnen 1994) and receptor binding (Cesarman et al. 1994) properties. The diverse contexts in which PAs are expressed may simply reflect the diverse contexts in which cells might encounter and must cope with fibrin. The known expression of PA by macrophages (Vassalli et al. 1992), keratinocytes (Morioka et al. 1987), capillary endothelial cells (Pepper 1987), granulosa cells (Sappino et al. 1989), renal tubule cells (Sappino et al. 1991), and many other cell types fits this overall concept. A critical tool in rigorously establishing any putative role of Plg outside of fibrinolysis will be mice lacking both fibrinogen and Plg. Abnormalities associated with Plg deficiency that are secondary consequences of a reduced ability to clear fibrin can be defined by comparing the phenotypes of $\mathrm{Plg}^{-1-}$ mice with fibrin(ogen)-free $\mathrm{Plg}^{-1-}$ mice. In this regard, fibrinogendeficient mice are already available (T.T. Suh and J.L. Degen, unpubl.), and we have begun the appropriate crosses to generate mice with combined Plg and fibrinogen deficiency.

If the only essential physiological role of Plg is fibrinolysis, then this does not preclude other important roles of Plg in disease pathophysiology. Notably, a linkage between PA or PA receptor expression and tumor cell invasiveness in vitro and in vivo is well established (Ossowski and Reich 1983; Danø et al. 1985, 1994; Mignatti et al. 1986; Ossowski 1988; Ossowski et al. 1991a,b; Crowley et al. 1993; Kook et al. 1994). Conceivably, tumor cells may depend or capitalize on the ability of plasmin to degrade both fibrin and other extracellular matrix components in the penetration of tissue barriers. Similarly, development of atherosclerotic lesions may depend on plasmin-mediated degradation of vessel wall components by smooth muscle cells. Each of these concepts can now be tested directly in vivo by breeding $\mathrm{Plg}^{-1-}$ mice to existing lines genetically predisposed to either malignant tumor formation (Guy et al. 1992) or atherosclerosis (Plump et al. 1992).

$\mathrm{Plg}^{-1-}$ mice also provide an opportunity to define physiological activators of single-chain uPA and tPA without the confounding background activity of plasmin. The finding that the level of activated, two-chain and low molecular weight uPA in the urine is unaffected by $\mathrm{Plg}$ deficiency argues that one or more proteases, other than plasmin, is available in the urogenital tract which is capable of activating pro-uPA and cleaving the light chain to produce enzymatically-active low molecular weight uPA. Proteases that are known to activate pro-uPA in vitro include plasma kallikrein, factor XIIa, and cathepsin B (Ichinose at al. 1986; Kobayashi et al. 1991). Because cathepsin $B$ is known to activate both free and receptor-bound pro-uPA, cleaves uPA at the same site as plasmin (Kobayashi et al. 1991), and is expressed 
Bugge et al.

by proximal tubule cells and secreted into the urine $(\mathrm{Ol}-$ bricht et al. 1991), this enzyme is a strong candidate for a urinary pro-uPA activating agent. However, direct studies are necessary to resolve which proteases activate uPA in the urogenital tract and to establish whether plasmin-independent PA activation also occurs outside the urogenital system.

\section{Materials and methods}

\section{Construction of targeting vector and generation of transgenic mice}

A bacteriophage $\lambda$ DASHII genomic DNA library, prepared using DNA from 129 /SvJ strain mice, was screened by in situ hybridization (Suh et al. 1994) with a 580-bp EcoRI-Nsil fragment from the mouse Plg cDNA (Degen et al. 1990) encoding the amino-terminal portion of Plg through the second kringle domain. Three positive isolates were found to contain both exons 1 and 2 by Southern blot analysis (Smith et al. 1980) with the following ${ }^{32} \mathrm{P}$-end-labeled exon 1- and 2-specific oligonucleotide probes: OligoEx1-5', 5'-CGGTGCTGTTGGCCAGTCCC-3'; and OligoEx2-5', 5'-GGGGACTCGCTGGATGGCTA-3'. Hybridizing DNA fragments from one recombinant bacteriophage, $\lambda \mathrm{mPlg}-1$, were subcloned into Bluescript II (Stratagene) plasmid vectors, and overlaps between each subclone were established based on restriction endonuclease cleavage sites and Southern blot analyses. DNA sequence was determined using plasmid templates (Suh et al. 1994) and both the Ex1-5' and Ex2-5' primers, and confirmed that the cloned gene encoded Plg; the gene organization over the first three exons was identical to the human Plg gene (Petersen et al. 1990), and the exon sequences were identical to the corresponding published mouse Plg cDNA sequences (Degen et al. 1990). The targeting vector was constructed by placing a 3.2-kb Sall cassette encoding HPRT /van der Lugt et al. 1991) between a 4-kb SacI-SmaI fragment derived from $5^{\prime}$-flanking sequences and a $1-\mathrm{kb}$ PstI fragment derived from intron 2 sequences. The Plg targeting vector was further modified with an herpes simplex virus thymidine kinase (HSV tk) cassette to provide a means of selection against cells that randomly inserted the transgene into the genome (Mansour et al. 1988). The targeting vector was introduced into E14TG2a ES cells (Hooper et al. 1987) by electroporating $(800 \mathrm{~V} / \mathrm{cm}$ and 200 $\mu \mathrm{F}$; IBI GeneZapper) $10^{8}$ cells suspended in $750 \mu \mathrm{l}$ of media containing $40 \mu \mathrm{g}$ of linearized targeting vector in a $0.4-\mathrm{cm} \mathrm{cu}-$ vette. The cells were maintained on mitomycin C-treated primary mouse embryonic feeder fibroblasts (Li et al. 1994) for 24 $\mathrm{hr}$ and then placed in selection media containing $0.1 \mathrm{mM}$ hypoxanthine, $16 \mu \mathrm{M}$ thymidine, $0.4 \mu \mathrm{M}$ aminopterin (HAT supplement; GIBCO), and $2 \mu \mathrm{M}$ ganciclovir (Syntex). After 7-11 days, 46 ES cell clones were picked and expanded in 24-well dishes, and DNA extracts were tested by PCR using an oligonucleotide primer complementary to a portion of Plg intron 2 that was not included in the targeting vector (OligoIn $2 ; 5^{\prime}$-AATGGCAGCCATCTTTCAGGCC- $3^{\prime} \mid$ and a primer complementary to the HPRT cassette (OligoHp; (5'-GGAAAAGCGCCTCCCCTACCCGG-3'). Two isolates produced a 1100-bp PCR product matching the size expected for cells incorporating the targeting vector by homologous recombination. Plg gene targeting was verified in each of these isolates by Southern blot hybridization analysis (Li et al. 1994) of EcoRI- and KpnI-digested genomic DNA using a 170 -bp PstI-EcoRI intron 2 probe that was external to the targeting vector sequences. Plg-targeted ES cells were injected into the blastocoel cavity of C57Bl/6-derived blastocysts and implanted into pseudopregnant females (Li et al.
1994). Chimeric male offspring were bred to NIH Black Swiss females (Taconic) to generate hemizygous offspring. These mice were subsequently interbred to generate homozygous $\mathrm{Plg}^{-1-}$ progeny.

\section{Genotype analyses}

Genotypes of mice were established using tail biopsy DNA preparations (Li et al. 1994) by either Southern blot analysis of EcoRI digests (see above) or PCR analysis. In the PCR assays, mice with one or two targeted Plg alleles were identified using reaction mixtures containing the primers, Oligoln2 and OligoHp (see above). Mice with one or two wild-type Plg alleles were identified using reaction mixtures containing the exon 2-specific primers OligoEx2-5' (see above) and OligoEx2-3' $\left(5^{\prime}-\right.$ TTCACATTTGGCCAAACAGT- ${ }^{\prime}{ }^{\prime}$, which yield a PCR product of $108 \mathrm{bp}$.

\section{Hematological analysis}

Blood was collected into one-tenth volume of $0.129 \mathrm{M}$ sodium citrate anticoagulant (Becton Dickinson) by insertion of a $27-$ gauge hypodermic needle into the inferior vena cava of mice anesthetized with $0.1 \mathrm{ml}$ per 30 gram of body weight of ketamine/xylazine/acepromazine $\{4: 1: 1\}$. Blood cell counts and hematocrit were established using a Technicon $\mathrm{H}-\mathrm{l}$ blood cell analyzer. Plasma was prepared from citrated blood by centrifugation at $2500 \mathrm{~g}$ for $10 \mathrm{~min}$ at room temperature. The thrombinstimulated clotting time was determined using plasma samples preincubated for $2 \mathrm{~min}$ at $37^{\circ} \mathrm{C}$ in glass tubes. The reaction mixtures were prepared by combining equal volumes of plasma and $20 \mathrm{U} / \mathrm{ml}$ of bovine thrombin diluted in PBS (Pacific Hemostasis\}.

\section{Northern blot analysis}

Total RNA was extracted from tissues frozen in liquid nitrogen using the guanidinium thiocyanate method (Chomczynski and Sacchi 1987). RNA concentrations were determined spectrophotometrically using an extinction coefficient of 20 at $260 \mathrm{~nm}$ for a $1 \mathrm{mg} / \mathrm{ml}$ solution. Samples $(40 \mu \mathrm{g})$ were electrophoretically fractionated on denaturing agarose gels, blotted onto BA85 nitrocellulose filters (Schleicher \& Schuell), and hybridized (Bell et al. 1990) to a ${ }^{32}$ P-labeled $\left(1.6 \times 10^{8}\right.$ to $\left.2.4 \times 10^{8} \mathrm{cpm} / \mu \mathrm{g}\right)$ 900-bp EcoRI fragment from the mouse Plg cDNA subclone MPL2 (Degen et al. 1990). To control for sample loading, rRNAs (28S and $18 \mathrm{~S}$ ) were visualized by UV transillumination of ethidium bromide-stained gels. Hybridized material was visualized and quantitated using phosphor screens and a Molecular Dynamics PhosphorImager equipped with ImageQuant software.

\section{Zymographic analysis of PA and Plg}

Plasma was prepared from citrated whole blood as described above. PA was detected by gel zymography as described previously (Heckel et al. 1990). Plg was detected using the same experimental procedure as for PA detection except that $20 \mathrm{IU} /$ $\mathrm{ml}$ of human high molecular weight uPA (American Diagnostica) was cast in the polyacrylamide gels rather than human Plg.

\section{Western blot analysis}

Proteins were fractionated by SDS-polyacrylamide gel electrophoresis ( $8 \%$ acrylamide) and transferred to Immobilon P membranes (Millipore) as described previously (Heckel et al. 1990). Plg was detected with a sheep anti-rat Plg antiserum that cross- 
reacts with mouse plasminogen (kindly provided by E. Reich). Mouse uPA was detected using affinity-purified rabbit antimouse uPA antibodies (Larsson et al. 1984). Bound primary antibody was detected using alkaline phosphatase-conjugated dog anti-sheep IgG or goat anti-rabbit IgG (Sigma) and the 5-bromo4-chloro-3-indolyl phosphate (BCIP)/nitro blue tetrazolium (NBT) (Sigma) staining system.

\section{Lysine-Sepharose enrichment of plasma Plg}

Freshly prepared citrated plasma samples $(150 \mu \mathrm{l})$ were diluted in an equal volume of buffer A $[0.15 \mathrm{~mm}$ potassium phosphate, $0.8 \mathrm{~mm}$ sodium phosphate, $14 \mathrm{~mm} \mathrm{NaCl}$, and $0.3 \mathrm{mM} \mathrm{KCl} / \mathrm{pH}$ 7.3)] and then combined with $100 \mu \mathrm{l}$ (settled volume) of lysineSepharose 4B (Pharmacia). The suspensions were incubated at room temperature for $30 \mathrm{~min}$ with continuous mixing. The Sepharose beads were collected by centrifugation at $3000 \mathrm{~g}$ for $\sim 30 \mathrm{sec}$ and resuspended in $1 \mathrm{ml}$ of buffer $\mathrm{A}$. This wash step was repeated eight times with the OD at $280 \mathrm{~nm}$ of the third wash being $<0.02$. Bound material was eluted from the lysine-Sepharose by a $30-\mathrm{min}$ incubation with an equal volume of buffer $\mathrm{A}$ containing $0.4 \mathrm{M} \epsilon$-amino caproic acid. The eluates were diluted in sample buffer containing $2 \%$ SDS for gel fractionation and subsequent $\mathrm{Plg}$ detection.

\section{Histology and fibrinogen immunostaining of tissue sections}

Mice were sacrificed under ketamine anesthesia (see above), and tissues were placed immediately into zinc-formalin fixative (U.S. Biotex). Tissues were fixed for $24 \mathrm{hr}$ and then processed into paraffin, sectioned, and stained by standard techniques. Immunostaining was performed using the Vectastain Elite ABC kit (Vector Laboratories) and nickel-enhanced diaminobenzidine stain.

\section{uPA esterase activity in urine}

Urine was collected directly (void urine) or by bladder puncture in ketamine-anesthetized mice (see above). The urine collected was either snap frozen in liquid nitrogen or placed directly into gel sample buffer containing $2 \%$ SDS. For immunoblotting, $5-\mu 1$ urine samples were fractionated by SDS-polyacrylamide gel electrophoresis ( $12 \%$ acrylamide), and uPA detected as described above. uPA esterase activity assays were performed using the uPA-specific chromogenic substrate, Spectrozyme-UK (American Diagnostica). Urine samples $(2 \mu \mathrm{l})$ were diluted in $100 \mu \mathrm{l}$ of $50 \mathrm{~mm}$ Tris- $\mathrm{HCl}$ buffer $(\mathrm{pH} 8.8)$ containing $0.01 \%$ Tween $80,10 \mathrm{KIU}$ aprotinin, and $2.5 \mathrm{~mm}$ Spectrozyme-UK and incubated at room temperature. Samples were read at $405 \mathrm{~nm}$ with the rate of substrate conversion still in the linear range.

\section{Acknowledgments}

We thank Drs. Sandra Degen, Keld Danø, Ed Reich, and Mary Jo Danton for their encouragement and advice, and for generously providing the mouse Plg cDNA, antibodies against PA, antibodies against $\mathrm{Plg}$, and $\mathrm{Plg}$, respectively. We are grateful to Kenn Holmbäck and John Duffy for their advice and expert assistance in generating gene-targeted transgenic mice. We also thank Ann Becker and Jean Snyder for their assistance in hematological and histological analyses. This work was supported by grants to J.L.D. from the National Institutes of Health (HL47826) and the National American Heart Association (with funds contributed by the AHA Ohio affiliate) (92-1103). This study was done during the tenure of an Established Investigatorship (J.L.D.) from the American Heart Association (93002570). T.H.B. was sup- ported by fellowships from the Danish Medical Research Council, the Danish Cancer Research Foundation, and the Danish Plasmid Foundation.

The publication costs of this article were defrayed in part by payment of page charges. This article must therefore be hereby marked "advertisement" in accordance with 18 USC section 1734 solely to indicate this fact.

\section{References}

Aoki, N., M. Moroi, Y. Sakata, and N. Yoshida. 1978. Abnormal plasminogen. A hereditary molecular abnormality found in a patient with recurrent thrombosis. J. Clin. Invest. 61: 11861195.

Azuma, H., Y. Uno, T. Shigekiyo, and S. Saito. 1993. Congenital plasminogen deficiency caused by $\operatorname{Ser}^{572}$ to Pro mutation. Blood 82: 475-480.

Bell, S.M., R.W. Brackenbury, N.D. Leslie, and J.L. Degen. 1990. Plasminogen activator gene expression is induced by the src oncogene product and tumor promoters. I. Biol. Chem. 265: 1333-1338.

Bode, V.C. and M.A. Dziadek. 1979. Plasminogen activator secretion during mouse embryogenesis. Dev. Biol. 73: 272289.

Carmeliet, P., L. Schoojans, L. Kieckens, B. Ream, J.L. Degen, R. Bronson, R. DeVos, J.J. van den Oord, D. Collen, and R.C. Mulligan. 1994. Physiological consequences of loss of plasminogen activator gene function in mice. Nature 368: 419424.

Cesarman, G.M., C.A. Guevara, and K.A. Hajjar. 1994. An endothelial cell receptor for plasminogen/tissue plasminogen activator (t-PA): Annexin II-mediated enhancement of t-PAdependent plasminogen activation. I. Biol. Chem. 269: 21198-21203.

Chomczynski, P. and N. Sacchi. 1987. Single-step method of RNA isolation by acid guanidinium thiocyanate-phenolchloroform extraction. Anal. Biochem. 162: 156-159.

Collen, D. and H.R. Lijnen. 1994. Fibrinolysis and the control of hemostasis. In The molecular basis of blood diseases (ed. G.S. Stamatoyannopoulos, A.W. Nienhuis, P.W. Majerus, and H. Varmus|, pp. 725-752. W.B. Saunders Co., Philadelphia, PA.

Crowley, C.W., R.L. Cohen, B.K. Lucas, G. Liu, M.A. Shuman, and A.D. Levinson. 1993. Prevention of metastasis by inhibition of the urokinase receptor. Proc. Natl. Acad. Sci. 90: 5021-5025.

Danø, K., P.A. Andreasen, J. Grøndahl-Hansen, P. Kristensen, L.S. Nielsen, and L. Skriver. 1985. Plasminogen activators, tissue degradation, and cancer. Adv. Cancer Res. 44: 139266.

Danø, K., N. Behrendt, N. Brünner, V. Ellis, M. Ploug, and C. Pyke. 1994. The urokinase receptor. Protein structure and role in plasminogen activation and cancer invasion. Fibrinolysis 8: 189-203.

Degen, S.J.F., S.M. Bell, L.A. Schaefer, and R.W. Elliott. 1990. Characterization of the cDNA coding for mouse plasminogen and localization of the gene to mouse chromosome 17 . Genomics 8: 49-61.

Deutsch, D.G. and E.T. Mertz. 1970. Plasminogen: Purification from human plasma by affinity chromatography. Science 170: $1095-1096$.

Dolan, G., M. Greaves, P. Cooper, and F.E. Preston. 1988. Thrombovascular disease and familial plasminogen deficiency: A report of three kindreds. Br. J. Haematol. 70: 417421. 
Ellis, V. and K. Danø. 1992. The urokinase receptor and the regulation of cell surface plasminogen activation. Fibrinolysis 6: $27-34$.

Friedman, G.C. and N. Seeds. 1994. Tissue plasminogen activator expression in the embryonic nervous system. Dev. Brain Res. 81: 41-49.

Girolami, A., F. Marafioti, M. Rubertelli, and M.G. Cappellato. 1986. Congenital heterozygous plasminogen deficiency associated with a severe thrombotic tendency. Acta Haematol. 75: 54-57.

Goldsmith, G.H., H. Saito, and O.D. Ratnoff. 1978. The activation of plasminogen by Hageman Factor (Factor XII) and Hageman Factor fragments. J. Clin. Invest. 62: 54-60.

Grainger, D.J., P.R. Kemp, A.C. Liu, R.M. Lawn, and J.C. Medcalfe. 1994. Activation of transforming growth factor- $\beta$ is inhibited in transgenic apolipoprotein $|\mathrm{a}|$ mice. Nature 370: 460-462.

Guy, C.T., R.D. Cardiff, and W.J. Muller. 1992. Induction of mammary tumors by expression of polyomavirus middle $T$ oncogene: A transgenic model for metastatic disease. Mol. Cell. Biol. 12: 954-961.

Heckel, J.L., E.P. Sandgren, J.L. Degen, R.D. Palmiter, and R.L. Brinster. 1990. Neonatal bleeding in transgenic mice expressing urokinase-type plasminogen activator. Cell 62 : 447-456.

Hooper, M.L., K. Hardy, A. Handyside, S. Hunter, and M. Monk. 1987. HPRT-deficient (Lesch-Nyhan) mouse embryos derived from germline colonization by cultured cells. Nature 326: 292-295.

Ichinose, A., K. Fujikawa, and T. Suyama. 1986. The activation of pro-urokinase by plasma kallikrein and its inactivation by thrombin. J. Biol. Chem. 261: 3486-3489.

Ichinose, A., E.S. Espling, J. Takamatsu, H. Saito, K. Shinmyozu, I. Maruyama, T.E. Petersen, and E.W. Davie. 1991. Two types of abnormal genes for plasminogen in families with a predisposition to thrombosis. Proc. Natl. Acad. Sci. 88: 115119.

Kielberg, V., P.A. Andreasen, J. Grøndahl-Hansen, L.S. Nielsen, L. Skriver, and K. Danø. 1985. Proenzyme to urokinase-type plasminogen activator in the mouse in vivo. FEBS Lett. 182: 441-445.

Kikuchi, S., Y. Yamanouchi, L. Li, K. Kobayashi, H. Ijima, R. Miyazaki, S. Tsuchiya, and H. Hamaguchi 1992. Plasminogen with the type-I mutation is polymorphic in the Japanese population. Hum. Genet. 90: 7-11.

Kluft, C., G. Dooijeward, and J.J. Emeis. 1987. Role of the contact activation system in fibrinolysis. Semin. Thromb. Hemostasis 13: 50-68.

Kobayashi, H., M. Schmitt, L. Goretzki, N. Chucholowski, J. Calvete, M. Kramer, W.A. Günzler, F. Jänicke, and H. Graeff. 1991. Cathepsin B efficiently activates the soluble and the tumor-cell receptor-bound form of the proenzyme urokinase-type plasminogen activator (pro-uPA). I. Biol. Chem. 266: 5147-5152.

Kook, Y. H., J. Adamski, A. Zelent, and L. Ossowski. 1994. The effect of antisense inhibition of urokinase receptor in human squamous cell carcinoma on malignancy. $E M B O J$. 13: 3983-3991.

Larsson, L.-I., L. Skriver, L.S. Nielsen, J. Gröndahl-Hansen, P. Kristensen, and K. Danø. 1984. Distribution of urokinasetype plasminogen activator immunoreactivity in the mouse. I. Cell Biol. 98: 894-903.

Li, H., D.P. Witte, W.W. Branford, B.J. Aronow, M. Weinstein, S. Kaur, S. Wert, G. Singh, C.M. Schreiner, J.A. Whitsett, W.J. Scott, and S.S. Potter. 1994. Gsh-4 encodes a LIM-type homeodomain, is in the developing nervous system and is re- quired for early postnatal survival. EMBO J. 13: 2876-2885. Lohnes, D., P. Kastner, A. Dierich, M. Mark, M. LeMeur, and P. Chambon. 1993. Function of retinoic acid receptor gamma in the mouse. Cell 73: 643-658.

Lottenberg, R., F.R. Dolly, and C.S. Kitchens. 1985. Recurrent thromboembolic disease and pulmonary hypertension associated with severe hypoplasminogenemia. Am. I. Hematol. 19: 181-193.

Mandle, R.J. and A.P. Kaplan. 1979. Hageman-Factor-dependent fibrinolysis: Generation of fibrinolytic activity by the interaction of human activated Factor XI and plasminogen. Blood 54: 850-862.

Mannucci, P.M., C. Kluft, D.W. Traas, P. Seveso, and A. D'Angelo. 1986. Congenital plasminogen deficiency associated with venous thromboembolism: Therapy trial with stanozolol. Br. J. Haematol. 63: 753-759.

Mansour, S.L., K.R. Thomas, and M.R. Capecchi. 1988. Disruption of the proto-oncogene int-2 in mouse embryo-derived stem cells: A general strategy for targeting mutations to nonselectable genes. Nature 336: 348-352.

Marotti, K.R., D. Belin, and S. Strickland. 1982. The production of distinct forms of plasminogen activator by mouse embryonic cells. Dev. Biol. 90: 154-159.

Mignatti, P., E. Robbins, and D.B. Rifkin. 1986. Tumor cell invasion through the human amniotic membrane. Requirement for a proteinase cascade. Cell 47: 487-498.

Morioka, S., G.S. Lazarus, J.L. Baird, and P.J. Jensen. 1987. Migrating keratinocytes express urokinase-type plasminogen activator. J. Invest. Dermatol. 88: 418-423.

Moscatelli, D. and D.B. Rifkin. 1988. Membrane and matrix localization of proteases: A common theme in tumor cell invasion and angiogenesis. Biochim. Biophys. Acta 948: 6785.

Odekon, L.E., F. Blasi, and D.B. Rifkin. 1994. Requirement for receptor-bound urokinase in plasmin-dependent cellular conversion of latent TGF- $\beta$ to TGF- $\beta$. I. Cell. Physiol. 158: $398-407$.

Olbricht, C.J., M. Fink, and E. Gutjahr. 1991. Alterations in liposomal enzymes of the proximal tubule in gentamicin nephrotoxicity. Kidney Int. 39: 639-646.

O'Reilly, M.S., L. Holmgren, Y. Shing, C. Chen, R.A. Rosenthal, M. Moses, W.S. Lane, Y. Cao, E.H. Sage, and J. Folkman. 1994. Angiostatin: A novel angiogenesis inhibitor that mediates the suppression of metastasis by Lewis lung carcinoma. Cell 79: 315-328.

Ossowski, L. and E. Reich 1983. Antibodies to plasminogen activator inhibit human tumor metastasis. Cell 35: 611619.

Ossowski, L. 1988. Plasminogen activator dependent pathways in dissemination of human tumors in the chick embryo. Cell 52: 321-328.

Ossowski, L., G. Clunie, M.-T. Masucci, and F. Blasi. 1991a. In vivo paracrine interactions between urokinase and its receptor: Effect on tumor cell migration. J. Cell Biol. 115: 11071112 .

Ossowski, L., H. Russo-Payne, and E.L. Wilson. 1991b. Inhibition of urokinase-type plasminogen activator by antibodies: The effect on dissemination of a human tumor in the nude mouse. Cancer Res. 51: 274-281.

Patrassi, G.M., M.T. Sartori, S. Piermarocchi, M. Viero, G. Boeri, and A. Girolami. 1993. Unusual thrombotic-like retinopathy (Coats' disease) associated with congenital plasminogen deficiency type 1. J. Int. Med. 234: 619-623.

Pepper, M.S., J.-D. Vassalli, R. Montesano, and L. Orci. 1987. Urokinase-type plasminogen activator is induced in migrating capillary endothelial cells. I. Cell Biol. 105: 2535-2541. 
Petersen, T.E., M.R. Martzen, A. Ichinose, and E.W. Davie. 1990. Characterization of the gene for human plasminogen, a key proenzyme in the fibrinolytic system. J. Biol. Chem. 265: 6104-6111.

Plump, A.S., J.D. Smith, T. Hayek, K. Aalto-Setala, A. Walsh, J.G. Verstuyft, E.M. Rubin, and J.L. Breslow. 1992. Severe hypercholesterolemia and atherosclerosis in apolipoprotein E-deficient mice created by homologous recombination in ES cells. Cell 71: 343-353.

Robbins, K.C. (1992). Dysplasminogenemias. Prog. Cardiovasc. Dis. 34: 295-308.

Rømer, J., L.R. Lund, J. Eriksen, C. Pyke, P. Kristensen, and K. Danø. 1994. The receptor for urokinase-type plasminogen activator is expressed by keratinocytes at the leading edge during re-epithelialization of mouse skin wounds. I. Invest. Dermatol. 102: 519-522.

Rudnicki, M.A., P.N. Schnegelsberg, R.H. Stead, T. Braun, H.H. Arnold, and R. Jaenish. 1993. MyoD or Myf-5 is required for the formation of skeletal muscle. Cell 75: 1351-1359.

Saksela, O. and D.B. Rifkin. 1988. Cell-associated plasminogen activation: Regulation and physiological functions. Annu. Rev. Cell. Biol. 4: 93-126.

Sappino, A.-P., J. Huarte, D. Belin, and J.-D. Vassalli. 1989. Plasminogen activators in tissue remodeling and invasion: mRNA localization in mouse ovaries and implanting embryos. J. Cell Biol. 109: 2471-2479.

Sappino, A.-P., J. Huarte, J.-D. Vassalli, and D. Belin. 1991. Sites of synthesis of urokinase and tissue-type plasminogen activators in the murine kidney. J. Clin. Invest. 87: 962-970.

Smith, G.E. and M.D. Summers. 1980. The bidirectional transfer of DNA and RNA to nitrocellulose or diazobenzyloxymethyl-paper. Anal. Biochem. 109: 123-129.

Strickland, S. and E. Reich. 1976. Plasminogen activation in early embryogenesis: Enzyme production by trophoblast and parietal endoderm. Cell 9: 231-240.

Suh, T.T., C. Nerlov, K. Danø, and J.L. Degen. 1994. The murine urokinase-type plasminogen activator receptor gene. J. Biol. Chem. 269: 25992-25998.

Valinsky, J.E. and E. Reich. 1981. Plasminogen activator in the bursa of Fabricius: Correlations with morphogenetic remodeling and cell migrations. Cell 25: 471-476.

van der Lugt, N., E.R. Maandag, H. teRiele, P.W. Laird, and A. Berns. 1991. A pgk-hprt fusion as a selectable marker for targeting genes in mouse embryonic stem cells: Disruption of the T-cell receptor $\delta$-chain encoding gene. Gene 105: 263267.

Vassalli, J.-D., A.-P. Sappino, and D. Belin. 1991. The plasminogen activator/plasmin system. $J$. Clin. Invest. 88: 10671072.

Vassalli, J.-D., A. Wohlwend, and D. Belin. 1992. Urokinasecatalyzed plasminogen activation at the monocyte/macrophage cell surface: A localized and regulated proteolytic system. Curr. Top. Microbiol. Immunol. 181: 65-86.

Werb, Z., C. Mainardi, C.A. Vater, and E.D. Harris. 1977. Endogenous activation of latent collagenases by rheumatoid synovial cells. Evidence for a role of plasminogen activator. N. Engl. J. Med. 296: 1017-1023. 


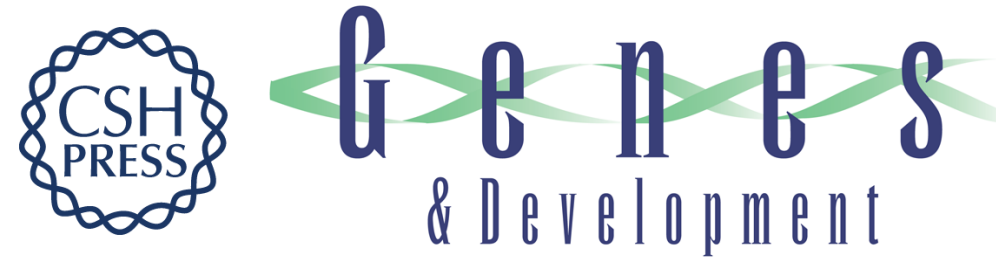

\section{Plasminogen deficiency causes severe thrombosis but is compatible with development and reproduction.}

T H Bugge, M J Flick, C C Daugherty, et al.

Genes Dev. 1995, 9:

Access the most recent version at doi:10.1101/gad.9.7.794

References This article cites 64 articles, 17 of which can be accessed free at:

http://genesdev.cshlp.org/content/9/7/794.full.html\#ref-list-1

License

Email Alerting

Service

Receive free email alerts when new articles cite this article - sign up in the box at the top right corner of the article or click here.

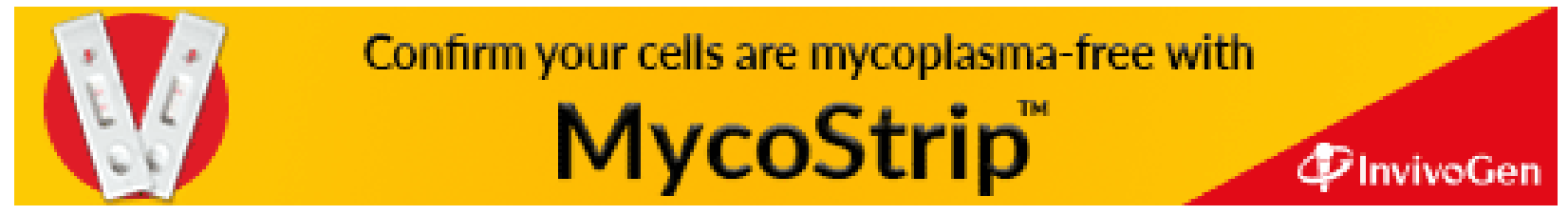

